\title{
A városi egészségfejlesztési tervezés mint a „lehetőségek ablakát" megnyitó eszköz - Székesfehérvár város példája
}

City health promotion planning as a vehicle towards opening the 'windows of opportunities' - an example of the City of Székesfehérvár, Hungary

Szerző: Girán János ${ }^{a} \bowtie$, Östör Annamária ${ }^{b}, V^{2}$ arga Márta ${ }^{c}$

a: Pécsi Tudományegyetem, Általános Orvostudományi Kar, Orvosi Népegészségtani Intézet,

b: Székesfehérvár MJV Önkormányzat, c: Székesfehérvár MJV Önkormányzata Humán

Szolgáltató Intézet

Beküldve: 2018. 05. 10.

doi: 10.24365/ef.v59i3.307

Összefoglaló: A magyarországi városi egészségfejlesztés tervezésének gyakorlatát tekintve Székesfehérvár város Egészségfejlesztési terve azon kevés stratégiai dokumentumok egyike, amelyek végrehajtása és értékelése megtörtént. Az Egészségfejlesztési terv megvalósitásának hatására - egyéb eredmények mellett - megalakításra került a helyi egészségfejlesztési programokat irányító szakmai testület, rendszeressé váltak a város által szervezett, egészségmegőrzést segítő közösségi programok, növekedett a rendszeresen sportoló felnőttek aránya. Tanulmányunk Székesfehérvár példáján mutatja be, hogy a városi egészségfejlesztési tervezés miként segít megnyitni a „lehetőségek ablakát” és biztosítani a közösségi alapú egészségvédelmi kezdeményezések politikai támogatottságát.

Kulcsszavak: városi egészségfejlesztési tervezés, egészségfejlesztési kezdeményezések politikai támogatása, WHO, Egészséges városok mozgalom

Summary: The City Health Promotion Plan of Székesfehérvár is one of the few city health promotion plans in Hungary, which has been implemented and evaluated. Owing to the activities related to the implementation of the plan, besides other results, a multisectoral steering committee has been established, the number of community-based local health promotion programmes has increased and the proportion of those adults who do sports regularly has risen. Based on the example of Székesfehérvár, our recent study explains how the health promotion plan was able to open the 'window of opportunities' to ensure political support for community-based health promotion initiatives.

Keywords: city health promotion planning, political support for health promotion, WHO, Healthy Cities Network

\section{BEVEZETÉS}

Napjainkban a világ népességének több mint fele (53,6\%), Európa lakosainak közel háromnegyede (73,4\%), míg a Magyarországon élő emberek több mint kétharmada $(70,8 \%)$ városlakó. A történelem során jelen évtizedben alakult ki először az a helyzet, hogy a városokban élők száma meghaladja a rurális környezetben élők számát, de az előreszámítások a városi népesség számának további emelkedését prognosztizálják. ${ }^{1}$ Mindebből következően a városi környezet negatív hatásai egyre több ember számára jelentenek egészségkockázatot. ${ }^{2}$ A modern városok ugyanakkor a mindennapi élet vonzó színtereiként jelennek meg: biztosítják a fejlett települési infrastruktúrát, a munkahelykínálat 
sokszínű és bőséges, a szolgáltatások magas színvonalon érhetők el. Ezek az adottságok azonban csakis akkor relevánsak, ha a helyi közösség tagjai egészségesek, és a lakóhelyük által biztosított előnyöket a maguk boldogulása érdekében képesek élvezni és kihasználni. A települési adottságok hatásai mindazonáltal az egyének egészségi állapotát mind negatív, mind pozitív módon alakíthatják. Az urbánus lét egyik számottevő ártalma lehet a krónikus nem fertőző betegségek kialakulásának fokozott veszélye, amit számos esetben egyéni életmódbeli kockázatok is súlyosbítanak. ${ }^{3}$ A város ugyanakkor azáltal, hogy széles körü hozzáférést biztosít az egészségügyi ellátásokhoz, a tanulási és munkalehetőségekhez, a kulturális programokhoz, valamint a sportolási és egyéb rekreációs tevékenységekhez, támogatja is az egészség megőrzését. E kettősséget jelzi az is, hogy bár a városi környezetben élők körében világszerte magasabb a krónikus nem fertőző betegségekben szenvedők aránya, az ezekre a betegségekre visszavezethető halandóság alacsonyabb - a fejlettebb diagnosztikai eljárásoknak és a könnyebb hozzáférhetőségnek köszönhetően -, mint a rurális környezetben élő népesség körében.

A települési környezettel kapcsolatos egészségkockázatok kezelését nehezíti továbbá, hogy egyrészt a - városi döntéshozók az egészségvédelmi szempontokra kevésbé érzékenyek. Másrészt a helyi döntések egészséghatásaival kapcsolatos visszacsatolási hajlandóság a népegészségügyi szakemberek részéről alacsony fokú. Harmadrészt a legtöbb település esetén a szakmai visszacsatolásnak és az arra épülő döntéshozói-szakmai együttmúködésnek nincs hatékonyan alkalmazható formája és bevett

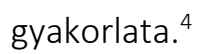

A városi környezet egészséghatásaival összefüggő feladatokkal mintegy három évtizede számos szakmai fórum foglalkozik. E területen jelenleg meghatározó iránymutatással szolgál az ENSZ által 2015-ben elfogadott, „Fenntartható fejlődési célok” címú dokumentumban felsoroltak közül a harmadik és a tizenegyedik cél' azáltal, hogy az alkalmazkodó városi környezetet, valamint az egészséget és a jóllétet a fenntartható fejlődés feltételeként határozza meg. ${ }^{5}$ Ezen összefüggést részletezi az
Egészségügyi Világszervezet által 2016-ban kiadott "Health as the Pulse of the New Urban Agenda" dokumentum, amely a városokban élők egészségének védelme érdekében a helyi döntések egészséghatásainak tudatos értékelését, valamint a szektorok közötti együttmúködés fontosságát hangsúlyozza. ${ }^{6}$ Mindezen előzményekre tekintettel a világ több mint száz polgármestere az Egészséges városok mozgalom sanghaji nyilatkozatában deklarálta egyetértését arra vonatkozóan, hogy az egészséges városi környezet kialakítása átfogó helyi cselekvést igényel, ezért

- az egészség védelmét célzó intézkedések minden városi szakpolitikai területen való megjelenése alapvető fontosságú;

- a városi stratégiai tervezési feladatokkal és a megvalósítandó fejlesztésekkel összefüggésben az egészség társadalmi, gazdasági és környezeti meghatározóinak alakítása elsődleges feladat;

- az egészség iránti közösségi elköteleződést a mindennapi élet színterein végzendő egészségvédelmi feladatokkal, az egészségmúveltség fokozásával, a társadalmi innovációk és az interaktív technológiák alkalmazásával is szükséges támogatni;

- az egészségügyi és szociális ellátások újragondolásával elő kell segíteni az esélyegyenlőség megteremtését;

- a szakpolitikai feladatok meghatározása és végrehajtása érdekében a városi jólét mértékét és az egészségkockázatok változását transzparens módon, folyamatosan kell értékelni ${ }^{7}$

Az Egészséges városok mozgalom a városi egészségvédelem területén 1988-ban indult. Az Egészségügyi Világszervezet Európai Régiójában 11 város köztük Pécs -részvételével szerveződött. A mozgalom fő célkitǔzése jelenleg is változatlan: elősegíteni, hogy a városokban élők egészségének védelme a helyi döntéshozói figyelem fókuszába kerülhessen. Így a tagvárosok a csatlakozáskor vállalják

- a mozgalom céljaival kapcsolatos legmagasabb szintű politikai elköteleződés kinyilvánítását;

\footnotetext{
'A Fenntartható fejlődési célok közül a 3. cél: „Biztosítani az egészséges életet és előmozdítani a jólétet mindenki számára minden korosztályban”, míg a 11. cél: „A városokat és emberi településeket befogadóvá, biztonságossá, alkalmazkodóvá és fenntarthatóvá tenni”.
} 
- a városi egészségfejlesztési terv kidolgozását és megvalósítását, valamint a mozgalom aktuálisan prioritásként kezelt témáiban való folyamatos feladatvállalást;

- a helyi kezdeményezések végrehajtását végző szervezeti struktúra és az interszektorális együttmúködés kialakítását.

Mindezen előfeltételek teljesülése eredményezheti azt, hogy a városi közpolitika az egészség védelmét, valamint az egészségkockázatok csökkentésére törekvő települési környezet kialakítását prioritásként kezeli. ${ }^{8}$

$\mathrm{Az}$ Egészséges városok mozgalom tagvárosaiban megvalósításra kerülő egészségvédelmi tevékenységek Európa-szerte ötéves munkaciklusokban, előre meghatározott prioritásokra alapozottan szerveződnek. A harmadik munkaciklus (1998-2002) egyik fő feladata a városi egészségfejlesztési tervezés módszerének helyi adaptációja, majd az egészségfejlesztési terv kidolgozása és megvalósítása volt. ${ }^{9}$ A városi egészségfejlesztési tervezés lényege a helyi döntéshozók és a szakmai ágensek között olyan multiszektorális együttmúködés kialakítása, amelyre alapozottan a városi egészségkockázatok mérséklése megvalósítható lehet. ${ }^{10}$ Magyarországon az Egészséges városok mozgalom nemzeti hálózata 1992-ben alakult, és jelenleg Egészséges Városok Magyar Nyelvű Szövetsége elnevezéssel 17 hazai és négy határon túli város együttmúködésének biztosít keretet." A szövetségi tagság a közösségi egészségfejlesztési programok szervezése mellett a városi egészségfejlesztési terv kidolgozásának és megvalósításának feladatait is magában foglalja.

Az egészségfejlesztési tervezés a hazai tagvárosokban több mint másfél évtizedes múlttal rendelkezik. Az első módszertani ajánlások megfogalmazása óta az ehhez kapcsolódó helyi tevékenységek a városok számára önként vállalt feladatot jelentettek. A közelmúltban változás történt: az Egészségügyről szóló törvény rendelkezései a 2015. évi CCXXIV. törvény 25 . § szerint a 152/B. §-sal kiegészülve a járásszékhelyek számára a járási egészségterv kidolgozását immáron kötelező feladatként írják elő. Mindazonáltal az egészségterv kidolgozását segítő egységes módszertani ajánlás jelenleg még hiányzik.
Az Egészséges Városok Magyar nyelvű Szövetsége tagvárosaiban használt egészségfejlesztési tervezési módszerrel a városok az említett törvényi kötelezettségnek eredményesen felelhetnek meg. A módszer alkalmazhatóságát a Székesfehérvárott 2011 és 2015 között megvalósított városi egészségfejlesztési terv tapasztalatai és eredményei is alátámasztják.

Székesfehérvár alapító tagként vesz részt az Egészséges Városok Magyar Nyelvű Szövetsége - és jogelődje - munkájában. A városi egészségfejlesztési terv kidolgozása 2010 tavaszán vette kezdetét. A helyzetértékelés eredményei alapján az egészségfejlesztési terv intézkedési területei a következő prioritások mentén fogalmazódtak meg:

- az egészségmegőrzés lehetőségeinek bővítése érdekében a helyi multiszektorális együttmúködési rendszer kialakítása;

- az egészségi állapotbeli egyenlőtlenségek csökkentésének elősegítése;

- az egészségi állapot javítását célzó döntések meghozatalakor a helyi közösségi részvétel erősítése;

- egyéni képességek fejlesztése a jobb egészségi állapot érdekében;

- az egészségügyi alapellátás feladatvállalásának fokozása az elsődleges prevenció területén;

- környezetegészségi kockázatok csökkentése. Az egészségfejlesztési terv kidolgozását Székesfehérvár MJV Önkormányzat Humán Szolgáltató Intézete koordinálta, valamint a megvalósítás operatív intézkedéseit irányította. A szakmai tevékenységek megvalósítására öt év időkeret állt rendelkezésre. A módszertani alapot a színtérmegközelítés jelentette. A programok múködéséhez szükséges pénzügyi feltételeket a város önkormányzatának aktuális költségvetésében nevesített éves forráskeret biztosította.

A közpolitikai térben egy adott téma napirendre kerülését Kingdon magyarázata szerint három egymástól független áramlat - a problémák, a megoldások, valamint a politika áramlata - befolyásolja. Amikor mindhárom áramlat egy ponton találkozik, megnyílhat a „lehetőségek ablaka”, amelyen keresztül egy adott téma a döntéshozók elé

\footnotetext{
ii Az Egészséges Városok Magyarországi Szövetsége 1992-ben 11 tagváros részvételével alakult. Annak érdekében, hogy a határon túli magyarlakta települések szövetséghez való csatlakozása is lehetővé váljon, a szervezet 2014-ben módosította alapszabályát és a nevét is megváltoztatta. Azóta, mint az Egészséges Városok Magyar Nyelvű Szövetsége múködik. (forrás: hahc.hu/index.php, letöltve: 2018.03.20.)
} 
kerülhet. ${ }^{11}$ Jelen írásunkban Székesfehérvár 2011 és 2015 között megvalósított egészségfejlesztési tervével összefüggésben mutatjuk be, hogy az egészségfejlesztési tervezés miként lehet képes megnyitni a "lehetőségek ablakát", és ezáltal a közösségi alapú egészségvédelmi kezdeményezések helyi politikai támogatottságát - mint a hosszú távú szakmai múködés előfeltételét - biztosítani.

\section{AZ EGÉSZSÉGFEJLESZTÉSI TERVEZÉS MÓDSZERE}

Az Egészséges Városok Magyar Nyelvű Szövetségének tagvárosai által alkalmazott egészségfejlesztési tervezési módszer első munkarészeként a városi egészségkép elkészítése történik meg. A városi egészségkép az adott városban élő emberek egészségi állapotának és az azt befolyásoló tényezőknek a leírása kvantitatív és kvalitatív módszerekkel. Ez az eszköz alkalmas arra, hogy a számos különféle helyen rendelkezésre álló információt összerendezze olyan komplex helyzetjelentéssé, amely egyébként nem található meg egyetlen adatgazdánál sem. Az egészségkép készítése az alábbi feladatokat foglalja magába:
- a város stratégiai szakpolitikai dokumentumainak elemzése;

- reprezentatív városi mintán végzett lakossági véleménykutatás;

- politikai döntéshozókkal felvett strukturált interjúk;

- helyzetfelmérés az Egészséges városok indikátorainak alkalmazásával.

$\mathrm{Az}$ egészségkép adatainak és információinak felhasználása megteremti a lehetőséget egyrészt a feltárt problématerületeken történő cselekvés kezdeményezéséhez, másrészt további kutatásokat generálhat a hatékony beavatkozásokhoz. Ugyanakkor már a kidolgozás folyamata is erősítheti annak a végső célnak a megvalósulását, hogy a döntéshozók figyelme ráirányuljon azokra a problémákra, amelyek megoldása a közösség tagjainak egészségi állapotát pozitívan befolyásolhatják. Ily módon az egészségkép alapul szolgálhat a helyi egészségterv vagy egészségfejlesztési terv prioritásainak megfogalmazásához, a cselekvési irányok kijelöléséhez, továbbá a szükséges források allokációjának és a szolgáltatások körének meghatározásához. ${ }^{12}$ Az egészségfejlesztési tervezés megalapozásának folyamatát az 1 . ábra mutatja.

1. ábra: Az egészségfejlesztési tervezés folyamata

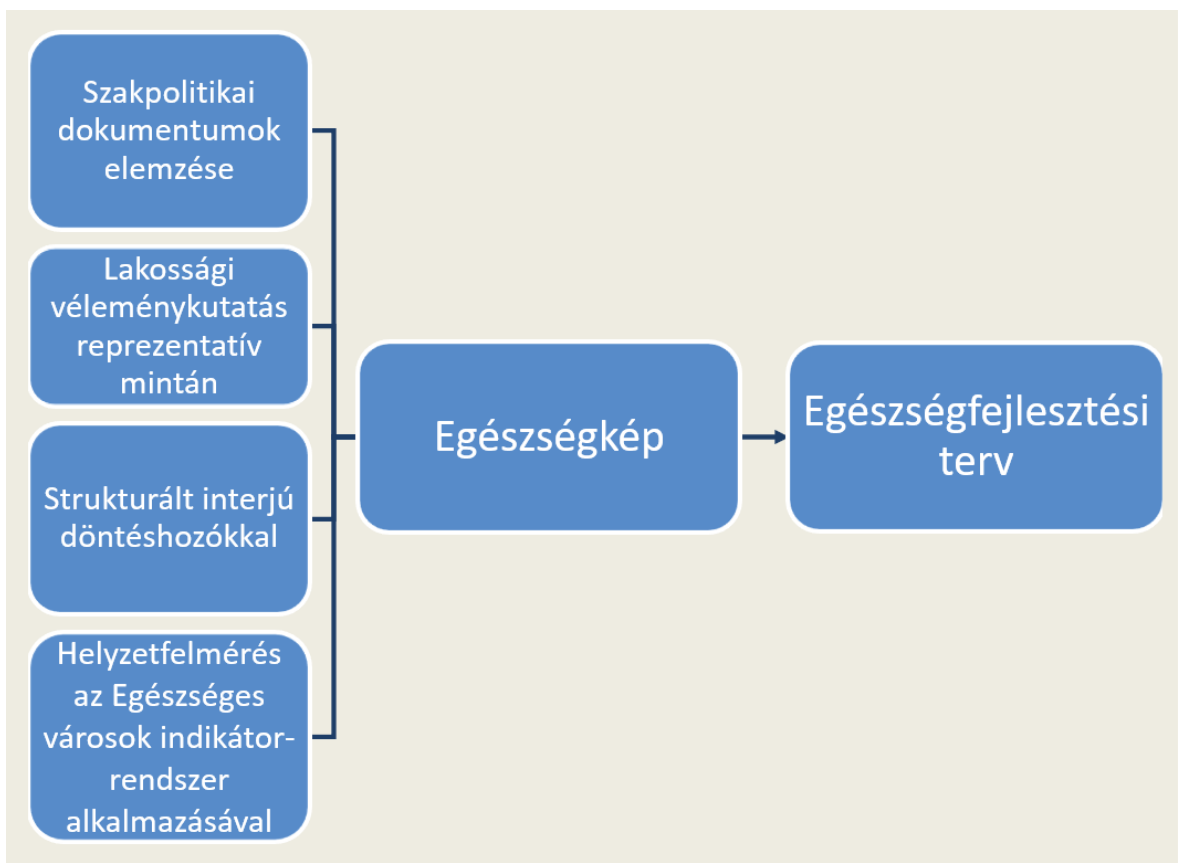

Forrás: saját szerkesztés 
A városi egészségkép készítésének egyes munkaszakaszai az alábbi szakmai tevékenységekre épültek.

\section{Helyi szakpolitikai dokumentumok elemzése}

A város szakpolitikai dokumentumának tekinthetők az ágazati koncepciók és programok (pl. sportkoncepció, környezetvédelmi program stb.) valamint a közép- és hosszú távú fejlesztési tervek és stratégiák (pl. integrált településfejlesztési stratégia, szociális szolgáltatások fejlesztési koncepciója stb.). E dokumentumok elemzésével feltárható, hogy a városi közpolitika múködése során mennyire hangsúlyosan jelennek meg az egészség védelmével kapcsolatos elképzelések, javaslatok, intézkedések. A vizsgálat keretében az egyes dokumentumokban keressük az egészséget támogató közpolitika érvényesülésére utaló hat alapelv szövegbeli attribútumait. ${ }^{13} \mathrm{Az}$ keresett alapelvek az egészségfejlesztés és az egészségpolitika meghatározó nemzetközi és hazai dokumentumainak alapelvei mentén kerültek megfogalmazásra az alábbiak szerint:

- Multiszektoralitás - Megjelenik-e a dokumentum szövegében több szakmai terület közös feladatvállalása a koncepcionális célok elérése érdekében, illetve azzal összefüggésben?

- Kimenetoldali vezérlés - A koncepcionális célok a felhasználók igényeit figyelembe véve fogalmazódnak-e meg, vagy objektív feltételekhez és elvárásokhoz igazodnak?

- Egészségre gyakorolt hatások általi vezérlés Egészségvédelmi, egészségfejlesztési törekvés megjelenik-e mint önálló cél vagy mint a koncepcionális célokkal összefüggő prioritás?
- Közösségi részvétel - A koncepcionális célok meghatározása vagy elérése érdekében megjelenik-e a különböző közösségi csoportok bevonását célzó intézkedés?

- Esélyegyenlőség biztosítása - Megjelenik-e a koncepcionális célok között, illetve azokkal összefüggésben valamely speciális társadalmi csoport sajátos igényeinek nevesítése?

- Környezeti kockázatok csökkentése - Megjelenik-e a dokumentumban olyan koncepcionális cél, amely a környezeti és környezetegészségi kockázatok csökkentésén keresztül törekedne az életminőség javítására?

Az elemzés során egy adott alapelv szövegbeli attribútuma explicit megjelenésúként értékelődik, ha a szövegszerú, konkrét megfogalmazás megtalálható volt a vizsgált dokumentumban. Implicit megjelenésnek minősül, ha a dokumentum a keresett alapelv attribútumát szövegszerüen ugyan nem tartalmazta, de valamely szövegrészének a jelentéstartalma azt magába foglalja. Az elemzés eredményei táblázatba rendezve összegződnek: a sorok az elemzett stratégiai dokumentumok megnevezését, míg az oszlopok az egészséget támogató közpolitika érvényesülésére utaló alapelveket mutatják. A cellákban lévő "," és ",-" jelzések az adott alapelv szövegattribútumának jelenlétét vagy hiányát jelzik. Az eredménytáblázat hipotetikus példáját az 1 . táblázat szemlélteti.

Az eredménytáblázat minden cellájához tartozik egy függelék, amely az elemzett dokumentum azon szövegrészét tartalmazza, ahol a keresett alapelv szövegattribútuma található. A 2. táblázat egy adott a dokumentum elemzési eredményeihez tartozó függeléket példázza.

1. táblázat: A dokumentumelemzés eredményeit tartalmazó táblázat hipotetikus példája

\begin{tabular}{|l|c|c|c|c|c|c|}
\hline & $\begin{array}{c}\text { Multi-szek- } \\
\text { toralitás }\end{array}$ & $\begin{array}{c}\text { Kimeneti } \\
\text { oldali ve- } \\
\text { zérlés - ál- } \\
\text { talában }\end{array}$ & $\begin{array}{c}\text { Egészségre } \\
\text { gyakorolt } \\
\text { hatás általi } \\
\text { vezérlés }\end{array}$ & $\begin{array}{c}\text { Közösségi } \\
\text { részvétel }\end{array}$ & $\begin{array}{c}\text { Esély- } \\
\text { egyenló- } \\
\text { ség bizto- } \\
\text { sítása }\end{array}$ & $\begin{array}{c}\text { Környezeti } \\
\text { és környe- } \\
\text { zetegészségi } \\
\text { kockázatok. }\end{array}$ \\
\hline Integrált városfejlesztési stratégia & + & + & - & + & + & + \\
\hline Drogellenes stratégia & + & + & + & + & + & - \\
\hline Sportkoncepció & - & - & + & + & + & - \\
\hline Turisztikai fejlesztési koncepció & + & + & + & - & - & + \\
\hline Humánerőforrás-fejlesztési stratégia & - & + & - & - & + & + \\
\hline Búnmegelőzési és közbiztonsági koncepció & + & + & + & + & + & - \\
\hline
\end{tabular}

Forrás: saját szerkesztés 


\section{BŪNMEGELŐZÉSI ÉS KÖZBIZTONSÁGI KONCEPCIÓ}

\section{AZ ALAPELV ÉRTELMEZÉSE}

Multiszektoralitás: Megjelenik-e a dokumentum szövegében több szakmai terület közös feladatvállalása a koncepcionális célok elérése érdekében, illetve azzal összefüggésben?

Kimeneti oldali vezérlés - általában: A koncepcionális célok a felhasználók igényeit figyelembe véve fogalmazódnak-e meg, vagy objektív feltételekhez és elvárásokhoz igazodnak-e?

\section{Az egészségre gyakorolt hatások általi vezérlés:}

Egészségvédelmi, egészségfejlesztési törekvés megjelenik-e mint önálló cél, vagy mint a koncepcionális célokkal összefüggő prioritás?

Közösségi részvétel: A koncepcionális célok meghatározása vagy elérése érdekében megjelenik-e a különböző közösségi csoportok bevonását célzó intézkedés?

Esélyegyenlőség biztosítása: Megjelenik-e a koncepcionális célok között, illetve azokkal összefüggésben valamely speciális társadalmi csoport sajátos igényeinek nevesítése?

\section{Környezeti és környezetegészségi kockázatok csök-}

kentése: Megjelenik-e a dokumentumban olyan koncepcionális cél, amely a környezeti, és környezetegészségi kockázatok csökkentésén keresztül törekedne az életminőség javítására?

\section{AZ ALAPELV DOKUMENTUMON BELÜLI ATTRIBÚCIÓJA}

- a Fórum résztvevői - a hatáskörök, a lehetőségek és a rendelkezésre álló eszközökre tekintettel - határozzák meg, hogy mely szervezet, mivel és milyen módon járulhat hozzá a probléma kezeléséhez. A hatékony cselekvés érdekében előremutató, ha a szervezetek a kötelező feladatok ellátásán túlmenően, az ügy iránt elkötelezettségüket kinyilvánítva önkéntes vállalásokkal is segítik a munkát. (21. oldal)

- a Fórum által végzett munka évente értékelésre kerül. A levont következtetéseket minden érintett szervezet számára hozzáférhetően szükséges közreadni, ezáltal is kezdeményezve a további együttmúködések kialakítását. (27. oldal)

- a Fórum a tevékenységét illetően a lakossági elvárásoknak kell hogy megfeleljen. Ennek érdekében folyamatosan figyelemmel szükséges kísérni a közvélemény-kutatási adatokat és a rendőrkapitány éves beszámolóit és egyéb lehetséges adatés információforrásokat (3. oldal)

- $\quad$ a prevenciós feladatvállalások között kiemelt figyelmet kell hogy kapjon az egészséges életmódra nevelés. (3. oldal)

- az ifjúság esetén a pszichés állapot romlása kedvezőtlen tendenciát mutat. A szenvedélybetegek és krónikus pszichiátria betegségben szenvedők hatékony ellátása érdekében cél az egészségügyi és szociális ellátások fejlesztése. (14. oldal)

- $\quad$ egyrészt biztosítani kell azokat a kommunikációs csatornákat és lehetőségeket, amelyek segítségével a városlakók a Fórum részére bejelentést, figyelemfelhívást, illetve javaslatokat tehetnek. Másrészt a Fórum munkájával kapcsolatos információkat a lakosság számára hozzáférhetővé kell tenni (12. oldal)

- $\quad$ minden városrészben, ahol szociálisan hátrányos helyzetű emberek élnek, integrációs közösségi programok biztosítása szükséges. A családok átmeneti otthona kiléptető rendszerének alapja további önkormányzati bérlakás biztosítása szükséges, ezáltal is lehetőséget biztosítva a családok tartós reintegrációját és megelőzve a családok szétesését (26. oldal)

- a potenciális visszaesés elkerülésének segítésére és az érintettek szegregálódásának megelőzése érdekében támogató programokat kell biztosítani (28. oldal)

Forrás: saját szerkesztés

\section{A dokumentumelemzés eredményei alapján} javaslatok fogalmazhatók meg, hogy szükség esetén miként lehetne az adott stratégiai dokumentumot úgy átdolgozni, hogy a dokumentum - és ezáltal várhatóan az arra alapozott szakpolitika egésze is az egészséget értékként kezelje, és az egészség védelmét támogassa.

\section{Lakossági véleménykutatás}

A lakossági véleménykutatás egyrészt a városlakók egészségi állapotával és egészség-magatartásával kapcsolatos alapvető jellemzők felmérését, másrészt a városi környezettel, mint az egészségi állapotot meghatározóan befolyásoló színtérrel 
kapcsolatos vélemények és igények megismerését foglalja magába. Az adatgyújtés a város felnőtt lakosságát nemek és életkor szerint reprezentáló városi mintán, személyesen vagy telefonon lekérdezett kérdőív alkalmazásával történik. A kérdőív fó kérdéscsoportjai a következők:

- a várossal mint lakóhellyel kapcsolatos vélemények;

- egyéni egészségi helyzettel és kockázatokkal kapcsolatos vélemények és ismeretek;

- a helyi egészségügyi ellátórendszerrel kapcsolatos vélemények;

- a helyi sportolási lehetőségekkel kapcsolatos vélemények;

- az egészségmegőrzés helyi lehetőségeivel kapcsolatos vélemények, ismeretek.

A programidőszak lezárását követően végzendő hatásvizsgálat kérdőíve egy további, a megvalósított programok értékelésével kapcsolatos kérdéscsoportot is tartalmaz.

\section{Strukturált interjúk döntéshozókkal}

E munkarész célja egyrészt az volt, hogy megismerjük, a helyi politikai döntéshozatali rendszer kulcsszereplői miként vélekednek a lakosság egészségi állapotának védelmét célzó városi feladatokról; másrészt hogy megismerjük, a döntéshozók miként tudnának hozzájárulni a lakosok egészségi állapotának védelméhez és a városi környezet egészségesebbé tételéhez személyes és döntéshozói kompetenciáik segítségével. Az interjúhelyzetekben kialakult beszélgetések alkalmat teremthetnek arra is, hogy a tisztségviselők és a bizottsági elnökök információt kaphassanak az egészségfejlesztési terv lényegéről, céljáról, várható hatásairól, valamint hogy a témával kapcsolatos kérdéseiket megfogalmazzák és azokra választ kapjanak.

\section{Helyzetfelmérés az Egészséges városok indikátor-rendszerével}

Az Egészséges városok mozgalom szakértői kidolgoztak egy 32 indikátort tartalmazó értékelési rendszert, amelynek segítségével egy adott város

- mortalitási és morbiditási mutatóiról;

- egészségügyi ellátórendszere releváns vonatkozásairól;

- épített és a természeti környezetéről;

- társadalmi-gazdasági környezetéről

egységes módszerrel készíthető helyzetelemzés. ${ }^{14}$ A helyzetfelméréshez használatos indikátorokat a 3. táblázat tartalmazza. Az indikátorok használata a helyi jellemzők időbeni és térbeni összehasonlítására is lehetőséget biztosít. ${ }^{15}$

\section{Mortalitási indikátorok}

1.1. Betegség miatti halálozás

1.2. Egyéb leggyakrabban előforduló halálokok

1.2. Alacsony testsúllyal születés

\section{Egészségügyi ellátórendszer indikátorai}

2.1. A város által szervezett egészségügyi oktatási programok száma

2.2. Védőoltásban részesült gyermekek száma

2.3. Egy háziorvosra jutó betegek száma

2.4. Egy nővérre jutó betegek száma

2.5. Társadalombiztosítási kártyával rendelkezők száma

2.6. Idegen nyelven hozzáférhető egészségügyi szolgáltatások

2.7. Az önkormányzat Közgyűlése által tárgyalt, az egészségügyhöz kapcsolódó előterjesztések száma 


\section{Környezetegészségi indikátorok}

\subsection{Légszennyezettségi adatok}

3.2. Vízminőségre vonatkozó adatok

3.3. A szennyvíz általi vízszennyezés mértéke a vízszennyező tényezőkön belül

3.4. A háztartási hulladék gyűjtésébe bekapcsolt háztartások száma

3.5. A háztartási hulladék kezelésének minőségi indexe

3.6. A városon belüli zöldfelületek aránya

3.7. A városi zöldfelületekhez való hozzáférés lehetősége a lakosság számára

3.8. Elhagyott ipari területek aránya a teljes területhez képest

3.9. Sport és szabadidős intézmények, lehetőségek száma

3.10. Sétálóutcák száma, hossza

3.11. A kerékpáros közlekedés helyzete a városban

3.12. A közösségi közlekedés helyzete a városban

3.13. A közösségi közlekedés által lefedett városrészek aránya

3.14. Az egy szobára jutó átlagos lakószám

\section{Társadalmi-gazdasági környezet indikátorai}

4.1. A komfort nélküli lakásokban élők (háztartások) száma

4.2. A hajléktalanok becsült száma

4.3. Munkanélküliségi ráta

4.4. Létminimum alatt élők száma

4.5. Bölcsődei, óvodai férőhelyek száma

4.6. Élveszülések száma a 20 évnél fiatalabb, 20-24 éves és a 35 év feletti nők csoportjaiban

4.7. Az abortuszok száma a szülések számához képest

4.8. A rokkantak foglalkoztatottsági mutatói

Forrás: Webster-Sanderson, 2012, p. $4 .{ }^{15}$

\section{Hatásvizsgálat}

Az egészségfejlesztési terv megvalósítását követően hatásvizsgálat lefolytatása történhet, amely módszereit tekintve megegyezik az egészségkép készítéséhez alkalmazott módszerekkel. A helyzetelemzés és a hatásvizsgálat során gyưjtött adatok összehasonlító elemzése tárhatja föl a beavatkozások eredményességét.

\section{AZ EGÉSZSÉGFEJLESZTÉSI TERVEZÉS TAPASZTALATAI}

A hazai városi egészségfejlesztési tervezés gyakorlatát tekintve Székesfehérvár 2011-ben elfogadott
Egészségfejlesztési terve azon kevés stratégiai dokumentumok egyike, amelyek a megyei jogú városokban élő népesség egészségi állapotának javítását célozták, és végrehajtásukat az önkormányzat eredményesnek ítélte. A tervezett intézkedések megvalósítását egyrészt a városi szakemberek elkötelezett feladatvállalása, másrészt a helyi politikai szereplők egészségfejlesztési feladatokat támogató hozzáállása tette lehetővé.

$\mathrm{Az}$ operatív munka elősegítése érdekében a helyi egészségfejlesztési kezdeményezéseket is koordináló Humán Szolgáltató Intézet egy fő főállású egészségfejlesztő szakember alkalmazására kapott lehetőséget. E létszámbővülés önmagában is az egészségfejlesztési terv egyik eredményét, és az intézkedések megvalósítási szándékának kinyilvání- 
tását jelentette. A helyi Multiszektorális Irányító Bizottság megalakulása és működése az elvégzett munkát illetően ugyancsak meghatározó jelentőségú volt. A testület az egészségfejlesztési kezdeményezésekhez széles körű és egységes szakmai hátteret biztosított. A mintegy 25 fős tagság a helyi egészségügyi alapellátási intézmények, a tisztiorvosi szolgálat, a civil szervezetek, a városüzemeltetésért felelős cégek, a Fejér Megyei Szent György Kórház, a városban működő oktatási intézmények, a rendőrség, a politikai döntéshozatal, valamint a Humán Szolgáltató Intézet munkatársaiból és képviselőiből formálódott. E szervezetek szakemberei a szervezési és irányítási feladatok mellett, az évente rendszeresen megrendezett tematikus közösségi egészségvédelmi programok és kezdeményezések megvalósításában is tevékenyen vállaltak feladatot. Ilyen rendezvényként említhetők a „Séta a mellrák ellen!” program, „A tiszta, egészséges Székesfehérvárért" futóverseny, a sportmajális, a diabetes világnapja, a nyílt nőgyógyászati szúrőnap, az elsősegélynyújtó tanfolyamok, a férfi szűrőnap, az anyatejes táplálás világnapja, a perifériás érbetegség szűrése, a „Jó szívvel Fehérvárért!" programok, a "Szívünk napja” rendezvények, a „Nemzetközi babahordozó hét" programjai, a vese világnapja, a „Szülők akadémiája” programsorozat, amelyek a hatásvizsgálat során a legtöbbek által ismert közösségi egészségfejlesztési kezdeményezésként jelentek meg. Az egészségfejlesztési tervezés megvalósítását jelentő intézkedések eredménye még az is - több más egyéb eredmény mellett -, hogy míg 2011-ben 1900 fő vett részt az egészségfejlesztési programokon, addig 2015-re ez a szám 10778 före változott, továbbá a hetente többször is rendszeresen sportolók aránya háromszorosára növekedett. ${ }^{16}$ iii

Az eredmények eléréséhez mindazonáltal a helyi szakemberek elkötelezett feladatvállalása mellett a helyi politikai szereplők aktív segítsége is meghatározónak bizonyult. Különösen fontos mindez azért, mert a döntéshozók megnyerése az egészségfejlesztési kezdeményezések támogatására a világ számos részén nehezen valósítható meg. ${ }^{17,18,19}$ A politikusok e területtel kapcsolatos, jellemzően tartózkodó hozzáállása egyrészt azon a tapasztalaton alapszik, hogy az egészségvédelemmel összefüggő tevékenységek esetén a hasznokat lényegesen nehezebb számszerúsíteni, mint a ráfordításokat, és míg a költségek előteremtése a jelen feladata, a hasznok csak jóval később realizálódnak. lly módon nehéz rövid időtávon belül eredményt felmutatni, továbbá a hasznok gyakran nem azokon a területeken jelentkeznek, ahonnan a költségek fedezete származott, miáltal az emberek az eredményeket nehezebben társítják a közpolitika egy-egy szereplőjéhez. ${ }^{20,21}$ Másrészt az egészségvédelem a legtöbb esetben nem jelenik meg kellően vonzó területként ahhoz, hogy a helyi politikus ezt is beválassza a politikai feladatvállalását jelentő portfóliójába. ${ }^{22,23}$ Székesfehérvárott az egészségfejlesztési terv intézkedéseinek megvalósításakor mindezen problémákat a döntéshozók személyes érintettségének kialakításával és a politikusok programszervezésbe történő bevonásával sikerült megoldani.

A politikusok személyes érintettségének fokozásához meghatározó segítséget jelentett, hogy a városvezetés tagjai az egészségfejlesztési terv kidolgozásába már az előkészítés során bevonásra kerültek. Ennek egyik módja a városi egészségvédelmi feladatokkal kapcsolatos strukturált interjúk felvétele volt. Hatékony támogatásfokozó eszköznek bizonyult az a kérdés, hogy az adott döntéshozó - illetve az általa vezetett bizottság - az egészségvédelem szempontjainak közpolitikai érvényesüléséhez miként járulhat hozzá. A válaszok között konkrét javaslatok szerepeltek, amelyek az egészségfejlesztési terv intézkedései között többségében meg is jelentek. Ily módon a képviselők a programjavaslatok támogatásával számos esetben a maguk által korábban megfogalmazott javaslatokat is megerősítették.

A programtervezés során alkalmazott decentralizált megközelítés a politikai támogatottság erősítése érdekében szintén meghatározó jelentőségúnek bizonyult. Ezáltal a városi lakosság egészét célzó rendezvények mellett, az egyes városrészekben is rendszeresen egészségnap és szürőnap került megszervezésre. E szemlélet további példája, hogy

\footnotetext{
iii Az eredményekről bővebb információt a „Székesfehérvár Megyei Jogú Város Önkormányzata Egészségfejlesztési Tervének felülvizsgálatát megalapozó lakossági véleménykutatás eredményei” című tanulmány tartalmaz. Az elemzés a „Javaslat Székesfehérvár Megyei Jogú Város Önkormányzat Egészségfejlesztési Tervével kapcsolatos intézkedések megtétele" című előterjesztés 2. mellékleteként teljes terjedelmében nyilvánosan hozzáférhető a megadott linken. Az előterjesztést az Önkormányzat Humán Közszolgálati Bizottsága a 2016. 06.23-án tartott nyílt ülésén a 3. napirendként tárgyalta.
} 
javarészt a képviselők egyénileg felhasználható támogatási keretének terhére a vizsgált időszakban városszerte 23 , új, szabadtéri fitneszpark is kialakításra került. Mindemellett az önkormányzat a helyben elérhető prevenciós feladatvállalásokat egyrészt a szemléltetést és a szűréseket segítő eszközök rendelkezésre bocsátásával, másrészt háziorvosi körzetenkénti éves pénzbeli hozzájárulással támogatta. A városrészekre fókuszáló egészségvédelmi események ugyanakkor a politikusok számára is lehetőséget biztosítottak, hogy nyomon követhessék a képviselt városrész lakóinak szánt támogatás hasznosulását. Másrészt az egyéni választókerülethez is köthető rendezvények lehetöséget biztosítottak arra is, hogy az ügy mögött támogatóként megjelenő politikusok is azonosithatóvá váljanak. Mindezek a megoldások biztosították a politikusok egyéni érdekeltségének fokozódását, de egyúttal a programok politikai támogatottságát is eredményezték.

Az ily módon létrejött kezdeményezések eredményeinek egy fontos elismerése, hogy 2017 márciusában Székesfehérvár a WHO European Healthy Cities Movement projektvárosai közé is felvételt nyert. $^{\text {iv }}$ Ezáltal a helyi közösség tagjait érintő egészségfejlesztési tevékenységekkel összefüggésben további nemzetközi szakmai támogatás vált elérhetővé.

\section{ZÁRÓGONDOLAT}

Székesfehérvár városában az Egészségfejlesztési terv kidolgozása és megvalósítása során nyílott meg a „lehetőségek ablaka”, miáltal a közösségi egészségfejlesztés a helyi közpolitikai témák között megjelenhetett, és a politikusok támogatását elnyerhette. Az egészségvédelmi feladatok politikai támogatottsága a hosszú távú fenntarthatóságuk érdekében meghatározó, mivel a lakosság egészségi állapotának javítása a döntéshozók elkötelezettsége nélkül nem lehetséges. ${ }^{24}$ Székesfehérvár városa az Egészségfejlesztési Terv megvalósításával ezirányú elköteleződését kinyilvánította.

A szerzők megjegyzése: Jelen tanulmány szerzői az Egészségfejlesztési terv kidolgozásban, megvalósításában és hatásvizsgálatában szakértői feladatvállalással müködtek közre.

\section{HIVATKOZÁSOK}

\footnotetext{
${ }^{1}$ World Urbanization Prospects: The 2014 Revision. United Nations, Department of Economic and Social Affairs, Population Division, CD-ROM Edition, 2014

2 Hidden cities: unmasking and overcoming health inequities in urban settings. WHO Centre for Health Development, Kobe and United Nations Human Settlements Programme (UN-HABITAT), 2010

${ }^{3}$ Galea, S., Vlahov, D. Urban health: evidence, challenges, and directions. Annual Review of Public Health 2005; (26): 341-65. doi: 10.1146/annurev.publhealth.26.021304.144708

${ }^{4}$ Report of the ICSU Planning Group on Health and Wellbeing in the Changing Urban Environment: a Systems Analysis Approach. International Council for Science, Paris, 2011

${ }^{5}$ ENSZ Fenntartható Fejlődés Célok 2030 http://www.unis.unvienna.org/unis/hu/topics/sustainable development goals background.html Elérve: 2018.06.09.

${ }^{6}$ Health as the pulse of the new urban agenda. World Health Organization. United Nations Conference on Housing and Sustainable Urban Development, Quito 2016 http://www.who.int/iris/handle/10665/250367 Elérve: 2018.06.09.

${ }^{7}$ Shanghai Consensus on Healthy Cities 2016 Healthy Cities Mayors Forum http://www.who.int/healthpromotion/conferences/9gchp/9gchp-mayors-consensus-healthy-cities.pdf?ua=1 Elérve: 2018.06.09.

${ }^{8}$ Twenty steps for developing a Healthy Cities project. 3rd edition, WHO Regional Office for Europe, Copenhagen, 1997

${ }^{9}$ De Blasio A, Girán J. Szemléletváltás az egészségfejlesztési tervezésben: A helyi döntéshozatal egészség- és környezettudatos támogatása. Magyar Epidemiológia. 2006;3(1):41-46.

${ }^{10}$ A Working Tool on City Health Development Planning: Concept, Process, Structure and Content. WHO Regional Office for Europe, Copenhagen, 2001
}

\footnotetext{
iv A projektvárosok a nemzeti hálózatokban való tagságuk mellett, közvetlenül a WHO Koppenhágai központjával is szakmai kapcsolatban állnak. Magyarországon Székesfehérvárral együtt három város, míg a WHO Európai Régiójának 30 országban mintegy 100 város rendelkezik ezzel a státusszal.
} 
${ }^{11}$ Kingdon JW. Agendas, Alternatives, and Public Policies. Longman Classics in Political Sciences. New York, 2003

${ }^{12}$ City Health Profiles - How to Report on Health in your City. WHO Regional Office for Europe, Copenhagen, 1995

${ }^{13}$ Krippendorff K. A tartalomelemzés módszertanának alapjai. Balassi Kiadó, Budapest. 1995, pp. 23-69.

${ }^{14}$ Webster P, Lipp A. The evolution of the WHO city health profiles: a content review. Health Promotion International. 2009;24(S1):i56-i63. doi: 10.1093/heapro/dap055

${ }^{15}$ Webster P, Sanderson D. Healthy Cities Indicators - A sustainable instrument to measure health? Journal of Urban Health. Bulletion of the New York Academy of Medicine. 2012. doi: 10.1007/s11524-011-9643-9

${ }^{16}$ Székesfehérvár Megyei Jogú Város Önkormányzata Egészségfejlesztési Tervének felülvizsgálatát megalapozó lakossági véleménykutatás eredményei. https://ekozig.szekesfehervar.hu/in-

dex.php?pg=page 140806\&dsKeyword=\&dsYear=2016\&dsCorporation=\&dsType=-2\&dsState=\&dsld=\&page=1\# Elérve: 2018. 01. 04.

${ }^{17}$ Mahler H. Towards a new public health. Health Promotion International. 1986;1(1):1. doi.org/10.1093/heapro/1.1.1

${ }_{18}$ McGinnis JM, Williams-Russo P, Knickman JR. The case for more active policy attention to health promotion. Health Affairs. 2002;21(2):78-93. doi 10.1377/hlthaff.21.2.78

${ }^{19}$ Catford J. Creating political will: moving from the science to the art of health promotion. Health Promotion International. 2006;21 (1):1-4. doi.org/10.1093/heapro/dak004

${ }^{20}$ Orosz É. The impact of social science research on health policy. Social Science and Medicine. 1994;39(9).

${ }^{21}$ Post LA, Raile ANW, Raile ED. Defining political will. Politics Policy. 2010;38(4):653-676. doi.org/10.1111/j.17471346.2010.00253.x.

${ }^{22}$ Lohmann S. Rational choice and political science. In: Durlauf SN, Blume LE (eds). The New Palgrave Dictionary of Economics, 2nd ed. Palgrave Macmillian, 2013

${ }^{23}$ Zalmanovitch Y, Cohen N. The pursuit of political will: politicians' motivation and health promotion. International Journal of Health Planning and Management. 2015;30:31-44. doi 10.1002/hpm.2203

${ }^{24}$ Orosz É. Félúton vagy tévúton? Egészségügyünk félmúltja és az egészségpolitika alternatívái. Egészséges Magyarországért Egyesület, Budapest, 2001 